\title{
A Study on the Demographic and Clinical Profile of Patients with Haemotoxic Snake Bite
}

\author{
Kalpana Ramanathan ${ }^{1}$, Haridoss Sripriya Vasudevan² \\ ${ }^{1}$ Associate Professor, Department of General Medicine, Govt. Stanley Medical College, Chennai, ${ }^{2}$ Associate Professor, Department of General Medicine, Govt. \\ Vellore Medical College, Vellore.
}

\section{Abstract}

Background: In India, snake bite is an important medical emergency and reason for hospital admission. There is a predominance of haemotoxic bites in South India. Factors contributing to fatal snake bite include problems with dosage of antivenom, delay in treatment and failure to observe and treat complications. Objectives: To study the demographic and clinical profile, complications and outcome in patients with haemotoxic snake bite. Subjects and Methods: This was a hospital based observational study conducted in a tertiary government hospital for a period of one year. The clinical and demographic profile of patients with haemotoxic snake bite and factors contributing to poor outcome were studied. Statistical analysis: Mean, Standard deviation, Percentiles and frequency, Percentages for continuous and categorical data, Chi square test for association between proportions and $\mathrm{p}<0.05$ for statistical significance. Results: A total of 100 patients of haemotoxic snake bite were studied. The majority were male patients (63\%) in the age group of 40-60 years. Most of the patients were farmers and labourers from a rural background. $92 \%$ of the patients were admitted within 6 hours of the bite. Local manifestations that were commonly seen were swelling of the bitten limb and tender lymphadenopathy. Bleeding manifestations were seen in $31 \%$. The most common complication was acute kidney injury seen in $10 \%$. Mortality rate was $3 \%$. Conclusion: Factors contributing to poor outcome were duration between bite and admission and presence of acute kidney injury.

Keywords: Haemotoxic snake bite - clinical profile - predictors of outcome.

Corresponding Author: Dr. Haridoss Sripriya Vasudevan, Associate Professor, Department of General Medicine, Govt. Vellore Medical College, Vellore.

Received: October 2019

Accepted: October 2019

\section{Introduction}

Snake bite is predominantly a rural problem that has important implications for the economy of the country. It is largely an occupational disease of farmers and plantation workers. Diagnosis of the species of the snake responsible for the bite is important for optimal clinical management. The big four medically important species has been considered to be Naja Naja, Bungarus caerulus, Dabioia russeli and Echis carinatus. Syndrome-species correlation studies in Tamil Nadu suggest the validity of the main syndromes in identifying the four main venomous snakes in this region. Haemotoxicity without AKI (Echis carinatus), haemotoxicity and neurotoxicity with or without renal failure (Daboia russeli), neurotoxicity with local swelling (Naga Naga) and neurotoxicity without local swelling (Bungarus caerulus). There is variation in the pattern of syndromes across India with haemotoxic viper bites predominating in south India and neurotoxic elapid bites in north India.

A hemotoxic snake bite is diagnosed from symptoms suggestive of systemic envenomation. Hemostatic abnormalities are prima facie evidence of Viperidae bite. Neurotoxic symptoms like ptosis can also be seen in a Russels viper bite. Viperidae bites can cause renal failure.
Signs and symptoms of viper bite include include:

1. The presence of significant local inflammation at the site of bite like severe pain, swelling, erythema or cyanosis.

2. Tender enlargement of lymph nodes draining the bitten part.

3. Hemoptysis, epistaxis, hematuria, hematemesis and melena, chemosis, macular bleed, gum bleeds, excessive menstrual bleed, bleeding from the bite site, bleeding into muscle, gingival bleed, bleeding into skin and mucous membrane showing as purpura or petechia.

4. Abdominal tenderness

5. Lateralizing neurological signs indicative of an intracranial bleed.

6. Deranged hemostatic profile suggested by either or all of an abnormal WBCT, PT > 1.5 times normal, APTT > 1.5 times normal.

7. Rise in serum creatinine $>30 \%$ of baseline value.

Renal failure is a common complication of Russells Viper bite. The contributory factors are intravascular haemolysis, DIC, direct nephrotoxicity, hypotension and rhabdomyolysis. Renal damage can develop very early, even when the patient arrives in the hospital soon after the bite. 
Viper bite victims may have venom induced bleeding and blood coagulation disturbances which can be corrected by anti-venom. Patients who still have active bleeding or clotting disturbances will require fresh frozen plasma infusions.

\section{Objective:}

The objective of this study is

1. To describe the demographic and clinical profile of patients with hemotoxic snake bite.

2. To study the complications and outcome in these patients.

\section{Subjects and Methods}

This was a prospective observational study done in the Department of General Medicine in a tertiary care government hospital between July 2017 and June 2018. The study was done after obtaining consent from the Institutional Ethical Committee. Patients were from Villupuram town and the surrounding villages.

All patients with evidence of haemotoxic snake bite as evidenced by prolongation of WBCT or presence of bleeding manifestations were included in this study. Patients with only neurological manifestations were excluded. Also excluded were those with unknown bite, liver, renal or connective tissue disease, known bleeding disorder and patients taking anticoagulant medication.

The demographic details like age, gender, occupation, urban or rural residence were noted. The identity of the snake was established by the patient's description of the snake, commonly referred to as Kannadiviriyan (Russel's viper) or Surattu pambu (Saw scaled viper), in Tamil. In some instances, the dead snake was brought by attenders. The time of bite and treatment at local hospital, if any was recorded.

The site of bite was noted. A thorough clinical examination was done in all patients. Signs of local envenomation like swelling, blistering, necrosis, local lymphadenopathy and compartmental syndrome were recorded. Systemic manifestations like epistaxis, gingival bleeding, hemoptysis, subconjunctival haemorrhages, haematemesis, bleeding per rectum and bleeding from the skin in the form of petechiae, purpura, ecchymoses and bleeding from site of bite were looked for in all patients. Abdominal tenderness indicative of bleeding into the abdominal cavity and lateralising neurological signs indicative of intracranial bleed were noted, if present.

WBCT was done in all patients on admission. The patient and attendants were counselled in the beginning that the test could be repeated several times. Positive (non-clotting) test indicated severe consumptive coagulopathy and antivenom treatment was started immediately. The WBCT was repeated every 6 hours until coagulation was restored. The test was carried out every one hour from admission for the first three hours. If it was normal, the test was repeated at 6 hour intervals for the remaining 24 hours. If the result was positive at any stage, antivenom was given and testing done every 6 hours as above.

The treatment provided was assessed by the timing and quantity of polyvalent ASV used during hospitalisation and compared with severity and outcome. Routine investigations including urea and creatinine estimation was done in all patients. AKI was defined in this study as an increase in serum creatinine concentration of more than 0.3 $\mathrm{mg} / \mathrm{dl}$ from baseline measured after admission or elsewhere after the snake bite or reduction in urine output to less than $0.5 \mathrm{ml} / \mathrm{kg} /$ hour for more than 6 hours. Patients with AKI were managed in consultation with a nephrologist. In patients with persistent severe bleeding, once antivenom was given, fresh frozen plasma was also transfused. All patients were followed up till death or discharge from the hospital.

\section{Statistical method used:}

Mean, Standard deviation, percentiles and frequency, Percentages were used to describe the continuous and categorical data respectively. To find an association between two attributes and to find difference between two proportions, Chi square test was used. The statistical significance level is considered at $\mathrm{p}<0.05$. The graphs are presented by using Microsoft Excel. The statistical Analysis was done by using SPSS (version 21.0)

\section{Results}

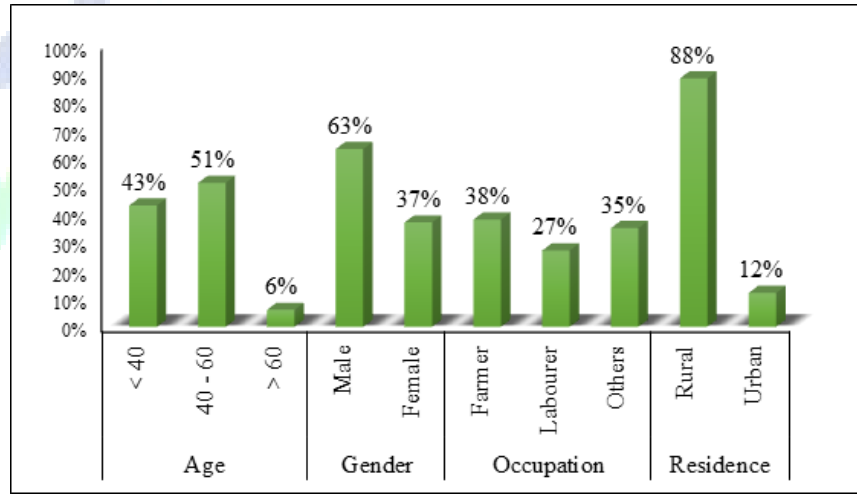

Figure 1: Demographic status of the snake bite patients

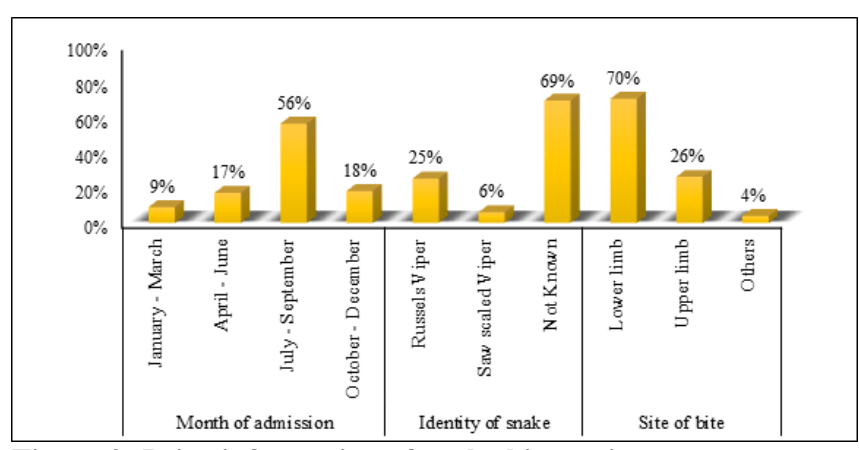

Figure 2: Prior information of snake bite patients

In this study, a total of 100 patients were studied. Most of the patients were in the age group of 40 to 60 years $(51 \%)$. $63 \%$ were male patients. The patients enrolled in this study were mainly farmers and labourers $(65 \%)$. The incidence of 
snake bite was more in the rural areas.

Most of the admission due to snake bite was in the rainy season during July to December. The snake was identified in only $31 \%$. The bite was due to Russel's viper in 25 patients and saw scaled viper in 6 . The most common site of bite was the lower limb (70\%). One patient had multiple bites, in both upper and lower limbs.

92\% were admitted within 6 hours of bite, of which $36 \%$ came within 2 hours of the bite. Only 1 patient was referred after 5 days for complications of the bite.

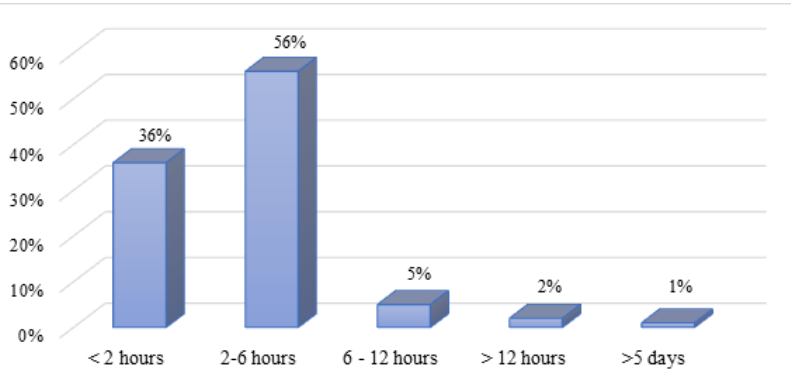

Figure 3: Duration between bite and admission

Regional manifestations of the bitten limb that were commonly seen in this study were local swelling and tender regional lymphadenopathy. The incidence of serious local manifestations like necrosis and compartmental syndrome was less at $1 \%$ and $4 \%$ respectively. Fasciotomy was done in 1 patient.

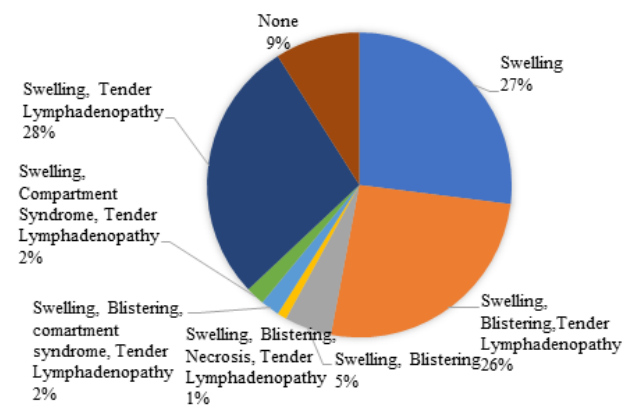

Figure 4: Local signs in snake bite patients.

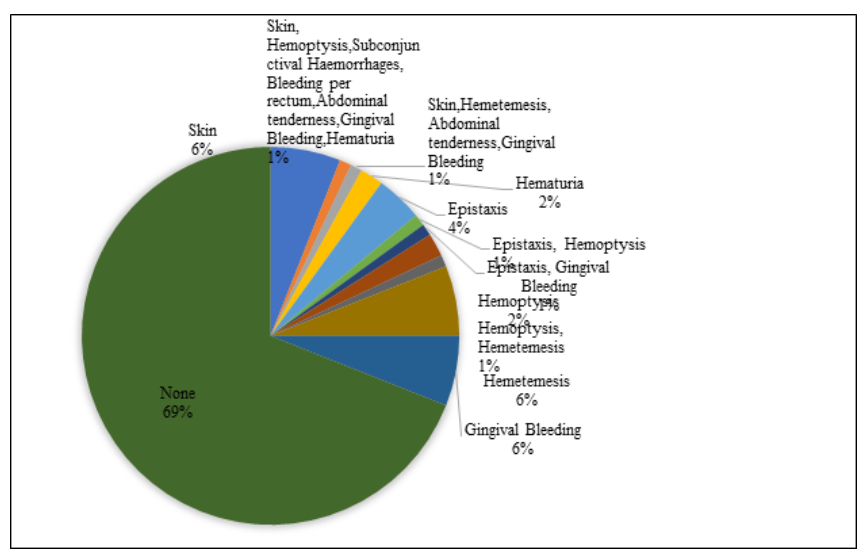

Figure 5: Systemic Manifestation in Snake bite patients

During the stay in hospital $31 \%$ had bleeding manifestations. Bleeding into the skin including wound site, gingival bleed, epistaxis and GI bleed were the common sites. $69 \%$ of the patients did not have any bleeding manifestations. 2 patients had negative WBCT, in spite of bleeding manifestations.

$52 \%$ of the patients had received ASV prior to admission. 93\% of the patients had coagulation parameters which returned to normal with less than 30 vials of ASV. Blood products were given in $16 \%$ of patients to control the bleeding.

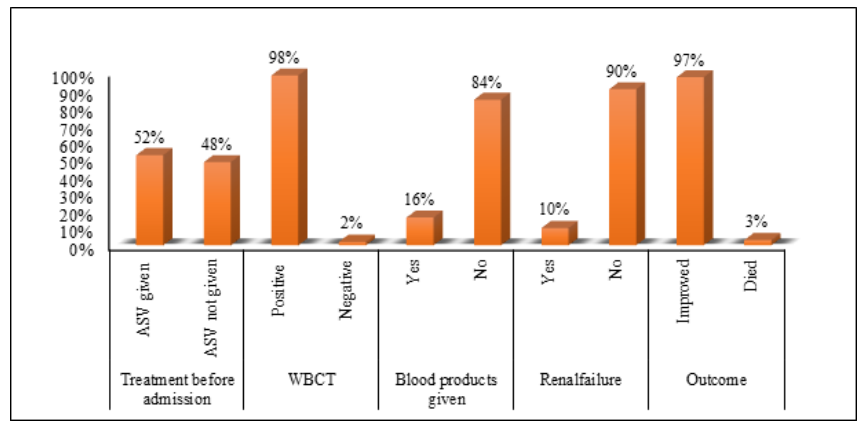

Figure 6: Patients' Status

\begin{tabular}{l}
\hline Table 1: Descriptive Statistics \\
\begin{tabular}{|l|l|l|l|}
\hline Characteristics & $\begin{array}{l}\text { Duration } \\
\text { between bite } \\
\text { and } \\
\text { admission } \\
\text { (hours) }\end{array}$ & $\begin{array}{l}\text { Age in } \\
\text { years }\end{array}$ & $\begin{array}{l}\text { No. of vials } \\
\text { of ASV } \\
\text { given }\end{array}$ \\
\hline Sample size (N) & $99 *$ & 100 & 100 \\
\hline Mean & 3.2 & 41 & 23 \\
\hline Median & 2.5 & 43.5 & 24 \\
\hline Mode & 2.5 & 50 & 16 \\
\hline Std. Deviation & 5.3 & 15.2 & 5.8 \\
\hline Minimum & 0.17 & 13 & 16 \\
\hline Maximum & 48 & 78 & 38 \\
\hline Percentiles 25 & 1 & 29 & 18 \\
\hline 50 & 2.5 & 43.5 & 24 \\
\hline 75 & 3.5 & 53.75 & 28 \\
\hline $\begin{array}{l}* 1 \text { case had duration }>5 \text { days hence excluded to avoid skewed distribution } \\
\text { of data of the variable. }\end{array}$ & & \\
\hline
\end{tabular}
\end{tabular}

\section{Interpretation:}

Duration between bite and admission (hours): The mean duration between bite and admission of the subjects was 3 hours and 20 minutes, 50\% subjects were below the 2.5 hours (two \& half hrs) and most of the subjects were took 2.5 hours. The Std. deviation showed that $68 \%$ subjects were deviated from the mean by 5 hours and $18 \mathrm{~min}$. (5.3 hrs).

The minimum duration was 10.2 minutes $(0.17 \mathrm{hrs})$ and maximum duration was 48 hours.

The 25 th percentile shows that $25 \%$ subjects were took the duration less than 1 hour.

The 50th percentile shows that $50 \%$ subjects were took the duration less than 2.5 hours.

The 75 th percentile shows that $75 \%$ subjects were took the duration less than 3.5 hour.

Age in years: In this study, the mean age of the subjects found 41 years, $50 \%$ subjects were having the age below the 43 years and 6 months $(43.5$ yrs.) and most of the subjects 
were 50 years old.

The Std. deviation shows that the age of total $68 \%$ subjects were deviated from below and above the mean age by 15 years and 2.4 months (15.2 yrs.)

The minimum age was 13 years and maximum age was 78 years found in this study.

The 25th percentile shows that the age of $25 \%$ subjects were less than 29 years.

The 50th percentile shows that the age of $50 \%$ subjects were less than 43 years and 6 months (43.5yrs)

The 75th percentile shows that the age of $75 \%$ subjects were less than 53 years and 9 months $(53.75 \mathrm{yrs})$

No. of vials of ASV given: An average 23 no. of vials of ASV were given to the subjects; $50 \%$ subjects were given less than 24 vials and most of the subjects were given 16 no. of vials.

The Std. deviation showed that $68 \%$ subject were given the no. of vials of ASV less and more by 5.8 vials from the mean no. of vials (23).

The minimum no. of vials of ASV was given 16 and maximum 38 .

The 25 th percentile shows that $25 \%$ subjects were given less than 18 no. of vials.

The 50th percentile shows that $50 \%$ subjects were given less than 24 no. of vials.

The 75 th percentile shows that $75 \%$ subjects were given less than 28 no. of vials.

The complications due to haemotoxic snake bite seen in this study were local complications like necrosis, compartmental syndrome and systemic complications like shock and AKI. AKI was present in 10\%, 3 patients received haemodialysis and the rest treated conservatively. $96 \%$ of the patients had a good outcome and were discharged. One patient was referred to higher centre. 3 patients died due to complications of snake bite.

In the assessment of factors affecting outcome in these patients, the following were the parameters assessed.

\section{Treatment before admission}

\begin{tabular}{|l|l|l|l|l|l|}
\hline Table 2.1: Treatment before admission. \\
\begin{tabular}{|l|l|l|l|} 
Treatment \\
before \\
admission
\end{tabular} & Outcome & $\begin{array}{l}\text { Pearson Chi- } \\
\text { Square } \\
\text { (Continuity } \\
\text { correction) }\end{array}$ \\
\cline { 2 - 5 } & Improved & Died & Total & $\begin{array}{l}\text { Test } \\
\text { Value, } \\
\text { df }\end{array}$ & $\begin{array}{l}\text { p } \\
\text { value }\end{array}$ \\
\hline ASV given & $51(53 \%)$ & $1(33 \%)$ & $\begin{array}{l}52 \\
(52 \%)\end{array}$ & $\begin{array}{l}0.005, \\
1\end{array}$ & 0.944 \\
\cline { 1 - 4 } $\begin{array}{l}\text { ASV not } \\
\text { given }\end{array}$ & $46(47 \%)$ & $2(67 \%)$ & $\begin{array}{l}48 \\
(48 \%)\end{array}$ & \\
\hline Total & $97(100 \%)$ & $\begin{array}{l}3 \\
(100 \%)\end{array}$ & $\begin{array}{l}100 \\
(100 \%)\end{array}$ & \\
\hline
\end{tabular}

In the association of treatment before admission and outcome, the improvement outcome found was not significant in the role of ASV given at $\mathrm{p}=0.944$
Table 2.2: Treatment before admission.

\begin{tabular}{|l|l|l|l|l|l|}
\hline $\begin{array}{l}\text { Treatment } \\
\text { before } \\
\text { admission }\end{array}$ & \multicolumn{2}{|l|}{ Complications including AKI } & \multicolumn{2}{|l|}{$\begin{array}{l}\text { Pearson Chi- } \\
\text { Square } \\
\text { (Continuity } \\
\text { Correction) }\end{array}$} \\
\cline { 2 - 5 } & Yes & No & Total & $\begin{array}{l}\text { Test } \\
\text { Value, } \\
\text { df }\end{array}$ & $\begin{array}{l}\text { p } \\
\text { value }\end{array}$ \\
\hline ASV given & $8(67 \%)$ & $\begin{array}{l}44 \\
(51 \%)\end{array}$ & $\begin{array}{l}52 \\
(52 \%)\end{array}$ & $\begin{array}{l}0.194, \\
1\end{array}$ & $\begin{array}{l}0.660 \\
(\text { NS) }\end{array}$ \\
\hline $\begin{array}{l}\text { ASV not } \\
\text { given }\end{array}$ & $4(33 \%)$ & $\begin{array}{l}44 \\
(49 \%)\end{array}$ & $\begin{array}{l}48 \\
(48 \%)\end{array}$ & \\
\hline Total & $12(100 \%)$ & $\begin{array}{l}88 \\
(100 \%)\end{array}$ & $\begin{array}{l}100 \\
(100 \%)\end{array}$ & \\
\hline
\end{tabular}

The proportion of ASV given and ASV not given was found not significant at $\mathrm{p}=.660$, in the association of complications including AKI.

\section{Duration between Bite and Admission}

\begin{tabular}{|c|c|c|c|c|c|}
\hline \multirow[b]{2}{*}{$\begin{array}{l}\text { Duratio } \\
\text { n } \\
\text { between } \\
\text { bite and } \\
\text { admissi } \\
\text { on }\end{array}$} & \multicolumn{3}{|c|}{ Outcome } & \multicolumn{2}{|c|}{ Pearson Chi-Square } \\
\hline & $\begin{array}{l}\text { Improv } \\
\text { ed }\end{array}$ & Died & Total & $\begin{array}{l}\text { Test Value, } \\
\text { df }\end{array}$ & $\begin{array}{l}p \\
\text { value }\end{array}$ \\
\hline$<2$ hours & $\begin{array}{l}34 \\
(35 \%) \\
\end{array}$ & $\begin{array}{l}2 \\
(67 \%) \\
\end{array}$ & $36(36 \%)$ & \multirow[t]{5}{*}{$12.18,3$} & \multirow[t]{5}{*}{$\begin{array}{l}0.007 \\
* *\end{array}$} \\
\hline $\begin{array}{l}2-6 \\
\text { hours }\end{array}$ & $\begin{array}{l}56 \\
(58 \%)\end{array}$ & 0 & $56(56 \%)$ & & \\
\hline $\begin{array}{l}6-12 \\
\text { hours }\end{array}$ & $5(5 \%)$ & 0 & $5(5 \%)$ & & \\
\hline $\begin{array}{l}>12 \\
\text { hours }\end{array}$ & $2(2 \%)$ & $\begin{array}{l}1 \\
(33 \%)\end{array}$ & $3(3 \%)$ & & \\
\hline Total & $\begin{array}{l}97 \\
(100 \%)\end{array}$ & $\begin{array}{l}3 \\
(100 \%)\end{array}$ & $\begin{array}{l}100 \\
(100 \%)\end{array}$ & & \\
\hline
\end{tabular}

In table 3.1, improved outcome was highly and significantly associated with duration between bite and admission at $\mathrm{p}=$ 0.007

Table 3.2: Duration between bite and admission.

\begin{tabular}{|l|l|l|l|l|l|}
\hline \multirow{2}{*}{$\begin{array}{l}\text { Duratio } \\
\text { netween } \\
\text { bite and } \\
\text { admissi } \\
\text { on }\end{array}$} & \multicolumn{2}{|l|}{ Complications with AKI } & \multicolumn{2}{|l|}{ Pearson Chi-Square } \\
\cline { 2 - 5 } & Yes & No & Total & $\begin{array}{l}\text { Test } \\
\text { Value, df }\end{array}$ & p value \\
\hline $\begin{array}{l}<2 \\
\text { hours }\end{array}$ & $3(25 \%)$ & $\begin{array}{l}33 \\
(38 \%)\end{array}$ & $\begin{array}{l}36 \\
(36 \%)\end{array}$ & $4.70,3$ & $\begin{array}{l}0.196 \\
\text { (NS) }\end{array}$ \\
\hline $\begin{array}{l}2-6 \\
\text { hours }\end{array}$ & $6(50 \%)$ & $\begin{array}{l}50 \\
(57 \%)\end{array}$ & $\begin{array}{l}56 \\
(56 \%)\end{array}$ & \\
\hline $\begin{array}{l}6-12 \\
\text { hours }\end{array}$ & $2(17 \%)$ & $3(3 \%)$ & $5(5 \%)$ & & \\
\hline $\begin{array}{l}>12 \\
\text { hours }\end{array}$ & $1(8 \%)$ & $2(2 \%)$ & $3(3 \%)$ & & \\
\hline Total & $\begin{array}{l}2 \\
(100 \%)\end{array}$ & $\begin{array}{l}88 \\
(100 \%)\end{array}$ & $\begin{array}{l}100 \\
(100 \%)\end{array}$ & & \\
\hline
\end{tabular}

In [Table 3.2], the complications with AKI in subjects were not significantly dependent on the duration between bite and admission at $\mathrm{p}=0.196$ 


\section{$\underline{\text { Association between Local Manifestations and AKI }}$}

In [Table 4], the proportion of local signs in the association of complications including AKI (12 cases) were significantly lower at $\mathrm{p}=0.0001$ as compared to no complications (88 cases). Although table no 4, also shows that some serious local signs such as, necrosis, compartment syndrome were associated with complications including AKI. (5 cases $/ 12,42 \%$ )

\section{Table 4: Association between Local Manifestations and AKI.}

\begin{tabular}{|c|c|c|c|c|c|}
\hline \multirow[t]{2}{*}{ Local Signs } & \multicolumn{3}{|c|}{ Complications with AKI } & \multicolumn{2}{|c|}{ Pearson Chi-Square } \\
\hline & Yes & No & Total & Test Value, df & p value \\
\hline Swelling & $1(8 \%)$ & $26(30 \%)$ & $27(27 \%)$ & \multirow[t]{5}{*}{$38.28,8$} & \multirow[t]{5}{*}{$0.0001^{* * *}$} \\
\hline Swelling, Blistering, Tender Lymphadenopathy & $4(34 \%)$ & $22(25 \%)$ & $26(26 \%)$ & & \\
\hline Swelling, Blistering & $1(8 \%)$ & $4(5 \%)$ & $5(5 \%)$ & & \\
\hline Swelling, Blistering, Necrosis, Tender Lymphadenopathy & $1(8 \%)$ & 0 & $1(1 \%)$ & & \\
\hline Swelling, Blistering, compartment syndrome, Tender Lymphadenopathy & $2(17 \%)$ & 0 & $2(2 \%)$ & & \\
\hline Swelling, Compartment Syndrome, Tender Lymphadenopathy & $2(17 \%)$ & 0 & $2(2 \%)$ & & \\
\hline Swelling, Tender Lymphadenopathy & $1(8 \%)$ & $27(30 \%)$ & $28(28 \%)$ & & \\
\hline None & 0 & $9(10 \%)$ & $9(9 \%)$ & & \\
\hline Total & $12(100 \%)$ & $88(100 \%)$ & $100(100 \%)$ & & \\
\hline
\end{tabular}

\section{Association with Number of Vials of ASV Used}

Table 5: Association with Number of Vials of ASV Used.

\begin{tabular}{|l|l|l|l|l|l|}
\hline \multirow{2}{*}{$\begin{array}{l}\text { No. } \\
\text { of } \\
\text { vials } \\
\text { give } \\
\text { n }\end{array}$} & \multicolumn{2}{|l|}{ Complications with AKI } & \multicolumn{2}{l|}{ Pearson Chi-Square } \\
\cline { 3 - 5 } & Yes & No & Total & $\begin{array}{l}\text { Test Value, } \\
\text { df }\end{array}$ & p value \\
\hline $\begin{array}{l}<=3 \\
0\end{array}$ & $9(10 \%)$ & $\begin{array}{l}84 \\
(90 \%)\end{array}$ & $\begin{array}{l}93 \\
(100 \%)\end{array}$ & $38.28,8$ & $\begin{array}{l}0.0001^{* *} \\
*\end{array}$ \\
\hline$>30$ & $3(43 \%)$ & $4(57 \%)$ & $7(100 \%)$ & \\
\hline Total & $\begin{array}{l}12 \\
(12 \%)\end{array}$ & $\begin{array}{l}88 \\
(88 \%)\end{array}$ & $\begin{array}{l}100 \\
(100 \%)\end{array}$ & \\
\hline
\end{tabular}

[Table 5], shows significant association between No. of vials given and complications of the patients $(\mathrm{p}=0.007)$. The requirement of Number of vials given $<=30$ had complications in 9 cases only (out of 93) whereas more number of vials (>30) were given (out of 7) 3 (43\%) cases had complications including AKI.

\section{Association of Outcome with Complications}

\begin{tabular}{|c|c|c|c|c|c|}
\hline \multirow[t]{2}{*}{$\begin{array}{l}\text { Outco } \\
\text { me }\end{array}$} & \multicolumn{3}{|c|}{ Complications including AKI } & \multicolumn{2}{|c|}{$\begin{array}{l}\text { Pearson Chi-Square } \\
\text { (Continuity } \\
\text { Correction) }\end{array}$} \\
\hline & Yes & No & Total & $\begin{array}{l}\text { Test } \\
\text { Value, df }\end{array}$ & p value \\
\hline Died & $3(25 \%)$ & 0 & $3(3 \%)$ & \multirow[t]{3}{*}{$13.527,1$} & \multirow{3}{*}{$\begin{array}{l}0.0001 * \\
* *\end{array}$} \\
\hline $\begin{array}{l}\text { Improv } \\
\text { ed }\end{array}$ & $\begin{array}{c}9 \\
(75 \%)\end{array}$ & $\begin{array}{l}88 \\
(100 \%)\end{array}$ & $97(97 \%)$ & & \\
\hline Total & $\begin{array}{l}12 \\
(100 \%)\end{array}$ & $\begin{array}{l}88 \\
(100 \%)\end{array}$ & $\begin{array}{l}100 \\
(100 \%)\end{array}$ & & \\
\hline
\end{tabular}

In [Table 6], in the association of outcome and complications including AKI, improvement of subjects 9 (75\%) were highly significant as compared to subjects who died, $3(25 \%)$ due to complications at $\mathrm{p}=0.0001 * * *$, whereas $88(100 \%)$ improved in the group without complications.

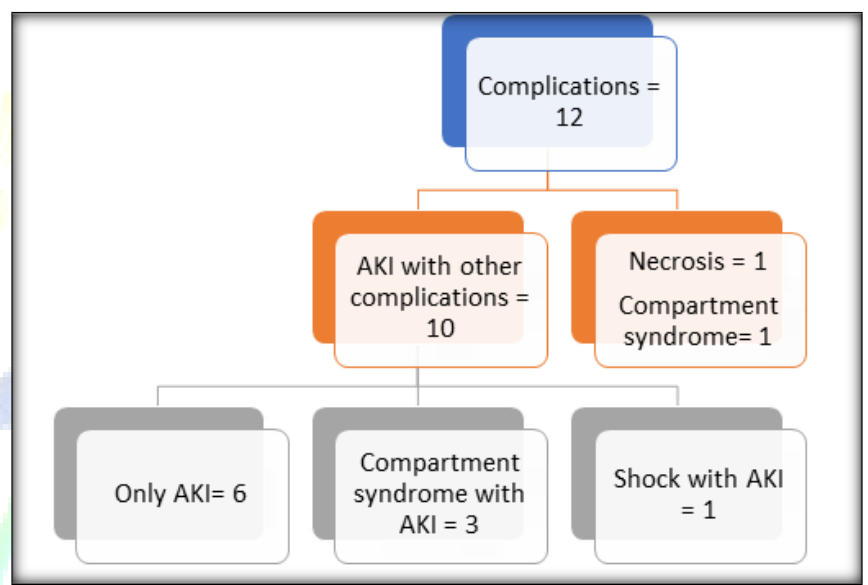

\section{Discussion}

Snake bite is a common medical emergency especially among the rural population of South India. This study was carried out to describe the demographic and clinical features of haemotoxic snake bite and study the factors associated with complications and outcome in these patients. There is a predominance of haemotoxic viper bites in South India. ${ }^{[1]}$ Males are bitten more often than females. The percentage of males was $63 \%$ in this study. This is because males are more often engaged in farming and other outdoor activities, especially in rural areas. $88 \%$ of patients enrolled in this study were from rural regions. ${ }^{[2]} 38 \%$ were involved in farming. $51 \%$ of the patients belonged to the age group 40 to 60 years and $43 \%$ were less than 40 years. The actively working age group has maximum risk of coming into contact with snakes.

Lower limb bites predominate at $70 \%$, similar to other studies, ${ }^{[3]} 26$ in upper limb and 4 patients over other sites. 1 patient had multiple bites. One of the reasons for severe envenomation is multiple strikes. ${ }^{[4]}$ One patient was admitted in hospital within 1 hour and 10 minutes of the bite and administered a total of 30 vials of ASV. He was 
bitten twice over the right lower limb, by a snake identified to be Russel"s viper. On admission he had cellulitis extending upto mid thigh and bleeding from bite site, gingival bleed, hematuria and bleeding per rectum. $\mathrm{He}$ developed renal failure and DIC. He was treated with HD, blood and plasma infusions, but died due to shock.

Most bites occur when the snake is trodden upon while walking barefoot in the fields. The snake was identified in only $31 \%$ of the patients. The snake was killed and brought along with the patient in some of these instances. The rest were identified by the local terminology used by the patient. The predominant snake identified was Russel's viper in $25 \%$, similar to the study by Abin Chandrakumar et al, where the incidence was $23.1 \%$. $^{[5]}$ The incidence of saw scaled viper bite was less at $6 \%$. Studies suggest that significant number of dead species should be brought to the hospital by the victims. This will provide sound epidemiological data and help in the identification of species that are causing morbidity and mortality in a given area. ${ }^{[6]}$

Factors identified as contributing to a fatal outcome included delayed hospital treatment or problems with antivenom use. In this study, $92 \%$ of the patients were admitted to the hospital within 6 hours, of which $36 \%$ reached the hospital within 2 hours of the bite. $52 \%$ of the patients were given ASV at the local hospital prior to admission. Early treatment can be attributed to the excellent ambulance transport system and timely referral by local hospitals in Tamil Nadu after early administration of ASV. Only 1 patient was admitted after 5 days for management of complications.

In this study, swelling of the bitten limb was the most common manifestation, seen in $88 \%$ of the patients. $50 \%$ of the patients had tender lymphadenopathy and $34 \%$ had blistering of the region. In a similar study in Jammu, ${ }^{[7]}$ local swelling was seen in $89 \%$ of viper bites. Serious complications like necrosis and compartmental syndrome were seen in $1 \%$ and $4 \%$ of patients respectively. Surgical debridement of necrotic tissue was done in 1 patient and fasciotomy in 1 patient with compartmental syndrome.

Evidence of coagulopathy is primarily detected by 20WBCT or visible spontaneous systemic bleeding. 20 WBCT is a simple, relatively inexpensive bedside test. It is considered the most reliable test of coagulation in haemotoxic bites which can be done at the bedside. ${ }^{[8]}$ In this study $98 \%$ of patients had positive $20 \mathrm{WBCT}$. $2 \%$ had negative test in spite of bleeding manifestations. In the study by Biradar et al, sensitivity of $20 \mathrm{WBCT}$ was $50 \%$ and specificity $89.13 \% .{ }^{[9]}$ More sensitive laboratory tests of blood coagulation like PT, aPTT, FDP and D- dimer assay were not done in this study.

Bleeding manifestations were seen in $31 \%$ of the patients in this study. The common sites of bleeding were bleeding into the skin including the site of bite, gingival bleed, epistaxis and GI bleed. ${ }^{[10]}$ The low incidence of bleeding manifestations is due to early administration of ASV in this study. ${ }^{[11]}$ Blood products, mainly fresh frozen plasma was used in $16 \%$ of patients to control the bleeding, in addition to ASV. The number of vials used was less than 30 vials in
$93 \%$ of the patients with an average of 23 vials. $7 \%$ patients needed more than 30 vials. The normal guidelines are to administer ASV every 6 hours until coagulation has been restored. A large study recently done in Kerala showed that up to 50 vials can been given for haemotoxic bites. ${ }^{[12]}$

AKI was the complication most frequently seen in this study in $10 \%$ of patients. Among the clinical features, independent positive association of AKI was noted with wound complications and prolonged bite to ASV time. ${ }^{[13]}$ Death occurred in $3 \%$ of patients.

In analysing the factors influencing complications and outcome in this study, significant positive association is noted between time of bite and admission and outcome. The patients getting treatment in less than 6 hours had improved outcome in $90 \%$ and death in $2 \%$. This is similar to the study by Raghavendra et al which showed improved outcome in $72 \%$ of patients admitted less than 6 hours 3 . One patient, 68 year old lady was admitted after 5 days of Russel's viper bite with cellulitis and renal failure. She had taken native treatment and was not treated with ASV. In hospital, wound debridement and hemodialysis was done but she succumbed to complications of the bite.

Prior treatment with ASV did not result in better outcome in this study, ${ }^{[14]}$ similar to the study by Rupal Padhiyar et al. The presence of serious local manifestations like necrosis and compartment syndrome were associated with increased incidence of AKI, similar to a study done by Dharod et al. $^{[15]}$ In this study, in those patients whose ASV requirement was more than 30 vials, incidence of complications were higher. In this study positive association was significantly seen between complications and outcome.

\section{Conclusion}

Snake bite is a major health issue in the rural regions of India.

WBCT test has relatively good sensitivity for the detection of venom induced consumption coagulopathy, still missed two cases where antivenom was potentially indicated. More sensitive tests like PT, aPTT, FDP or D- dimer may be used whenever possible.

Prompt admission to hospital and early administration of ASV reduces complications and improves outcome.

There is a need for well - designed and adequately powered national clinical dose finding studies to issue guidelines for doses of anti-venom use for snake bites prevalent in that region.

\footnotetext{
Acknowledgements

We wish to thank Dr. Aruna B. Patil, (Ph.D. Statistics), Assistant Professor in Biostatistics, Dept. of Community Medicine, ESIC-PGIMSR Medical College \& Hospital, Chennai, for her valuable contribution and guidance in conducting the statistical analysis and interpretation of the results. Her suggestions have been of immense help in the completion of this study.
} 


\section{References}

1. Vivek Chauhan, Suman Thakur: " The North South divide in snake bite envenomation in India" Review Article. J. Emergency Trauma and shock, Oct 2016, 9, 151-4.

2. Rajesh Krishnappa, Chandrika DG, Ramesh M. Gowda, Prakash Babu, Roopesh Banala: "A study on demographical and clinical profile and outcome in a tristate tertiary care centre" International Journal of Medical Science and Public Health, 2016, Vol 5, Issue 9.

3. J.C. Menon, Joseph JK, Jose MP, Dhananjaya BL, Oommen OV: "Clinical profile and laboratory parameters in 1051 victims of snake bite from a single centre in Kerala, South India." JAPI, Aug 2016, Vol 64.

4. Guidelines for the management of Snake Bites, 2nd ed, WHO 2016.

5. Abin Chandrakumar, TNK SuriyaPrakash, P. Linu Mohan, Levin Thomas, P.V. Vikas: "Evaluation of demographic and clinical profile of snake bite casualties presented at a tertiary care hospital in Kerala." Clinical Epidemiology and Global Health 4 (2016) 140 - 145

6. Raghavendra B. M., Neelam Devi Maravi, Debashish Barik, Soumya Iyengar: "Clinical Profile of Snake Bite in a Tertiary Care Hospital in South India." International Journal of Science and Research, March 2017, Volume 6, Issue 3.

7. Siddharth Kapoor: "Spectrum of Snake Bite Poisoning in Jammu - An Observational study" Journal of Evidence based Medicine and Health Care, November 2017, Vol 4, Issue 88, Pages 5139 - 5146.

8. J.C. Menon, J. K. Joseph, M.P. Jose, D. Punde, D.B. Mazumdar, H.S. Bawaskar et al : Management protocol of venomous snake bite in
India : a consensus statement. Toxin Review, 2016; 35(3-4) 147 - 151.

9. Manisha V. Biradar, Rahul Abhange : “ A study of laboratory parameters prothrombin time and 20 minute WBCT in snake bite patients “ MedPulse - International Medical Journal, October 2015, 2 (10): 697-701.

10. P. Ramamurthy, Deepak P. Kurahatti, Kumar N. Sunil, Malappa and Vishwanatha Huggi : "A study on coagulation profile and its prognostic significance in patients with snake bite envenomation" Journal of Evolution of Medical and Dental Sciences, October 9, 2014, Vol 3, Issue 51.

11. Geoffrey K. Isbister, Anjana Silva : "Addressing the global challenge of snake envenoming” Lancet, Vol 392, Aug 25, 2018.

12. Shibendu Ghosh, Prabuddha Mukhopadhyay, Tanmoy Chatterjee: "Management of Snake Bite in India" - Editorial Journal of The Association of Physicians of India, August 2016, Vol 64.

13. Vinay S. Panchalwar, Chandrashekar M. Atkar, Manu Vincent: "Early Prediction of Acute Kidney Injury by Clinical and Biochemical Parameters in Snake bite patients." Journal of Medical Science and Clinical Research, March 2017, Vol 5 Issue 3.

14. Rupal Padhiyar, Swati A. Chavan, Nivedita D. Moulick : "Snake Bite Envenomation in a Tertiary Care Centre" Journal of the Association of Physicians of India, March 2018, Vol 66.

15. Mridul.V. Dharod, Tushar. B. Patel, Archana S. Deshpande, Rajini.V. Gulhare, Mangesh B. Patil, Yogendra. V. Bansod : " Clinical predictors of AKI following snake bite envenomation." North American Journal of Medical Sciences, Oct 5 (10) 2013, 594 - 599.

Copyright: () the author(s), 2019. It is an open-access article distributed under the terms of the Creative Commons Attribution License (CC BY 4.0), which permits authors to retain ownership of the copyright for their content, and allow anyone to download, reuse, reprint, modify, distribute and/or copy the content as long as the original authors and source are cited.

How to cite this article: Ramanathan K, Vasudevan HS. A Study on the Demographic and Clinical Profile of Patients with Haemotoxic Snake Bite. Asian J. Med. Res. 2019;8(4):ME11-ME17.

DOI: dx.doi.org/10.21276/ajmr.2019.8.4.ME3 